einstein

Official Publication of the Instituto Israelita

de Ensino e Pesquisa Albert Einstein

ISSN: 1679-4508 | e-ISSN: 2317-6385
How to cite this article:

Meneghini KF, Hood CF, Menezes LO,

Mendoza-Sassi RA, Dumith SC. Influenza

vaccination coverage in elderly and high-risk adults: characterization of associated factors einstein (São Paulo). 2021;19:eA05830.

Corresponding author:

Samuel Carvalho Dumith

Rua Visconde de Paranaguá, 102 - Centro Zip code: $96203-900$ - Rio Grande, RS, Brazil Phone: (55 53) 3237-4623

E-mail: scdumith@yahoo.com.br

Received on:

May 6, 2020

Accepted on:

Nov 25, 2020

Conflict of interest:

none.

Copyright 2021

(c) BY

This content is licensed

under a Creative Commons

Attribution 4.0 International License.

\title{
Influenza vaccination coverage in elderly and high-risk adults: characterization of associated factors
}

\author{
Cobertura vacinal de influenza em idosos e adultos de alto risco: \\ caracterização dos fatores associados
}

\author{
Kevin Francisco Durigon Meneghini', Camila Furtado Hood², Letícia Oliveira de Menezes², \\ Raúl Andrés Mendoza-Sassi', Samuel Carvalho Dumith ${ }^{1}$ \\ 1 Faculdade de Medicina, Universidade Federal do Rio Grande, Rio Grande, RS, Brazil. \\ 2 Faculdade de Medicina, Universidade Católica de Pelotas, Pelotas, RS, Brazil.
}

DOI: 10.31744/einstein_journal/2021A05830

\section{ABSTRACT}

Objective: To evaluate the prevalence and factors associated with non-vaccination against influenza in the risk group. Methods: A cross-sectional, population-based study, carried out in the city of Rio Grande (RS). The outcome was defined as belonging to risk groups and not having been vaccinated in the last 12 months. Demographic, socioeconomic, behavioral variables, and access for health services were analyzed. Results: In this study, 680 individuals participated. The prevalence was $46.0 \%$ (95\%Cl: $41.8-50.3$ ), ranging from $27.9 \%$ (elderly) to $81.8 \%$ (pregnant women). Young adults, single, intermediate socioeconomic bracket, smoker, with depressive symptoms, who did not perform physical activity and did not consult a physician in the last year, had a higher prevalence of non-vaccination. Conclusion: Half of the sample was not vaccinated in the period. Due to the similarity of influenza-like illness and the coronavirus 2019 disease (COVID-19), increasing vaccination would minimize mortality and use of hospital beds due to influenza, optimizing the response of hospital capacity.

Keywords: Influenza vaccines; Barriers to access of health services; Health services research; Primary prevention; Public Health; Risk groups

\section{RESUMO}

Objetivo: Avaliar a prevalência e os fatores associados à não vacinação contra influenza em grupos de risco. Métodos: Estudo transversal, de base populacional, realizado em Rio Grande (RS). 0 desfecho foi definido como pertencer aos grupos de risco e não ter se vacinado nos últimos 12 meses. Foram analisadas variáveis demográficas, socioeconômicas, comportamentais e de acesso a serviços de saúde. Resultados: Participaram 680 indivíduos. A prevalência foi de $46,0 \%$ (IC95\%: 41,8-50,3), variando de 27,9\% (idosos) a 81,8\% (gestantes). Adultos jovens, solteiros, de nível econômico intermediário, tabagistas, com sintomas depressivos, que não praticavam atividade física e não consultaram um médico no último ano tiveram maior prevalência de não vacinação. Conclusão: Metade da amostra não foi vacinada no período. Pela semelhança da síndrome gripal com a doença pelo coronavírus 2019 (COVID-19), aumentar a vacinação minimizaria a mortalidade e a utilização de leitos hospitalares devido à influenza, otimizando a resposta da capacidade hospitalar.

Descritores: Vacinas contra influenza; Barreiras ao acesso aos cuidados de saúde; Pesquisa sobre serviços de saúde; Prevenção primária; Saúde Pública; Grupos de risco 


\section{INTRODUCTION}

Vaccine, from Latin vaccine, means "derived from cow". Edward Jenner was responsible for the records in the $18^{\text {th }}$ century. He observed that peasants were not affected by smallpox when in contact with infected cows ${ }^{(1,2)}$ which was recognized when the efficacy of the microorganism inoculation was verified in the immunological stimulation, with a lower number of people getting sick..$^{(1)}$

In Brazil, the first vaccination campaign, conceived by Osvaldo Cruz, took place in 1904 and focused on reducing smallpox morbidity and mortality. ${ }^{(1,2)}$ However, with the fear of the unknown and the population's misunderstanding, popular resistance was triggered, culminating in the revocation of compulsory vaccination and the failure of the campaign. This became known as the Vaccine Uprising. ${ }^{(1-3)}$

With better understanding of the population about the benefits of vaccination, the habit of vaccination was gradually created in the population and, due to the success achieved, and became compulsory approximately 50 years ago. Today, 20 vaccines are mandatory, aiming to protect people from controlled agents, which have already been responsible for decimating populations. ${ }^{(3)}$

The World Health Organization (WHO) is one of the agencies responsible for developing and researching vaccines, with the purpose of eradicating diseases, such as smallpox, poliomyelitis, and varicella. ${ }^{(2)}$ In Brazil, the agency responsible for the vaccination schedule and for measuring compliance with it is the Ministry of Health, through the National Immunization Program, adapting, within the territory, the most specific vaccination for each region. ${ }^{(2,3)}$ The National Immunization Program does not operate exclusively in Brazil; it is an international reference and partner of other countries, such as East Timor, Palestine, and the West Bank. ${ }^{(2)}$

In 1999, the first vaccination campaign against influenza aimed to reduce morbidity and mortality in the elderly due to their vulnerability, reaching $87.34 \%$ coverage, and exceeding the goal by $17.34 \% .^{(3)}$ After this success, this vaccine has been offered throughout the year and is part of the annual vaccination calendar. ${ }^{(3)}$ The vaccination goal increased according to the success of vaccination coverage and the demographic change demonstrated by the Brazilian Institute of Geography and Statistics (IBGE - Instituto Brasileiro de Geografia e Estatística)- from $80 \%$ in 2008 , and $90 \%$ in $2017,{ }^{(4)}$ covering between $89 \%$ and $92 \% .^{(5)}$

In 2020, Brazil was in its $22^{\text {nd }}$ influenza vaccination campaign, but with a different outlook: a new pandemic, the coronavirus 2019 disease (COVID-19) made the world and Brazil more attentive to influenza symptoms. ${ }^{(4,6)}$ Vaccine coverage in that year aimed mainly to facilitate the differential diagnosis between the common influenza syndrome and COVID-19, allowing a more accurate investigation and diagnosis, and reducing disease morbidity and mortality. ${ }^{(4,6)}$

Currently, the most vulnerable groups to infection, temporary immunosuppression, or risk of decompensation of the underlying disease are given priority. ${ }^{(7)}$ Among these, in addition to the elderly, are children aged between 6 months and 5 years; pregnant and postpartum women; healthcare and prison workers; indigenous peoples; population deprived of freedom; obese individuals; patients with chronic noncommunicable diseases (NCD), such as respiratory, cardiac, renal, hepatic, neurological conditions, and diabetes; patients with drug-induced or congenital immunosuppression; and trisomy carriers. ${ }^{(4)}$

In 2019, the vaccination coverage of risk group members exceeded $84 \% .^{(4)}$ Pregnant women and children had the lowest coverage (84\%), the only ones not reaching the goal. ${ }^{(4)}$ The elderly had vaccination coverage of roughly $99 \% .^{(4)}$ Other prioritized diseases accounted for $17 \%$ of doses applied in the campaign; among them, patients with chronic respiratory diseases, chronic heart diseases, and diabetes were responsible for $81 \%$ of doses within the group. ${ }^{(4)}$

Although it seems harmless, the influenza-like illness can present with severe signs and symptoms, and can progress to death. ${ }^{(4,7)}$ Depending on how the pathogen is introduced into the population, devastating consequences can occur, as in the 2009 pandemics of H1N1, ${ }^{\left({ }^{8,9}\right)}$ and currently, of COVID-19. ${ }^{(6)}$ The official statistics published until July 2020 reported a mortality rate of $3.9 \%$ in Brazil. ${ }^{(10)}$ When healthy persons are infected, they are more likely to present with mild symptoms or be asymptomatic. However, individuals with an existing condition or a debilitating health status have a higher likelihood of being severely affected by the disease. ${ }^{(7)}$

In Brazil, respiratory diseases are frequent causes of hospitalization (nearly 640 thousand admissions in 2019), especially in the elderly population. Even with an average stay of 6 days, many demanded prolonged hospitalizations, beds in intensive care unit (ICU), and sometimes evolved to death. In 2019, the mortality rate was 9.45 per 100 thousand inhabitants. ${ }^{(4,7,11)}$

Some people become unprotected, whether included or not in the priority group ${ }^{(4)}$ and some reasons for not vaccinating are fear, belief that it does not work, perception of a low risk of disease, unpleasant experience 
with previous immunizations, lack of knowledge, and not understanding the provision by the Unified Health System (SUS - Sistema Único de Saúde).(12) The vaccination campaign has an educational nature, since it introduces general knowledge about influenza, explains the importance of the act, demonstrates possible morbidity and mortality of the disease, and promotes population immunization. ${ }^{(3,4)}$

Even with the high coverage rates presented by the campaign, population surveys that contribute to the official data are needed, aiming to identify factors (socioeconomic, demographic, lifestyle, comorbidities, proximity to the Primary Healthcare Unit, and registration of users) associated with non-vaccination, to assist health managers in identifying characteristics that require greater attention, so that the goal of vaccination coverage is achieved. ${ }^{(12)}$

\section{OBJECTIVE}

To evaluate the prevalence and factors associated with non-vaccination against influenza in at-risk groups.

\section{METHODS}

The city of Rio Grande is located in the state of Rio Grande do Sul, in the extreme south of Brazil, with approximately 200 thousand inhabitants, 95\% living in the urban area. Its economy is mainly based on port activities. The city Human Development Index (HDI) is 0.744 and the Gross Domestic Product (GDP) per capita is $\mathrm{R} \$ 36,816.67 .{ }^{(13)}$ In addition, the city has two hospitals, one of which is totally dedicated to SUS, and 32 Primary Healthcare Unit.

This study derived from the project Saúde $d a$ População Rio Grandina, (Health of Rio Grande population), which investigated diseases and risk factors in individuals aged over 18 years, in the urban area of Rio Grande, excluding those institutionalized in nursing homes, hospitals, prisons, and those with physical and/or cognitive disabilities that prevented them from answering the questionnaire. Data was collected in 2016. More methodological details can be found in an earlier publication. ${ }^{(13)}$

Two sample calculations were performed. The first checked the prevalence of the outcomes, and the second, factors associated with the outcomes. The sampling process was composed of two stages: first the census sectors, followed by the households. We carried out a systematic selection, choosing 72 out of
293 eligible census sectors (25\%), ten households per sector on average, selecting more sectors, and fewer households, minimizing the design effect.

The outcome was considered as not having received an influenza vaccine in the 12 months prior to the survey. Only individuals who were in risk groups according to the Ministry of Health were considered in the denominator: $^{(4)}$ the elderly; pregnant women; patients with chronic NCD (respiratory, cardiac, renal, diabetes mellitus type 1 or type 2 on medication, and obesity grade III), and indigenous people. The independent variables included were sex (male or female), age group (in years), skin color (white or others), marital status (married, single, or widowed/separated), education (in years), asset index (in terciles), smoking (non-smoker and current smoker), excessive alcohol consumption (yes or no), physical activity (yes or no), food insecurity (yes or no), level of stress (in terciles), self-perception of health status (excellent/very good, good, fair/poor), depressive symptoms (yes or no), having health insurance (yes or no), having seen a doctor in the last 12 months (yes or no), having been visited by a community health worker (yes or no/does not know), and household registered in the neighborhood Primary Healthcare Unit (yes or no/does not know).

The asset index was obtained by analysis of the main components on a 11-item list of household assets or characteristics. The first component that explained $30 \%$ of variance in all variables (eigenvalue of 3.3 ) was extracted and divided into terciles. Excessive alcohol consumption was defined as consuming five or more drinks for men and four or more drinks for women in the past month. ${ }^{(14)}$ Physical activity was measured using the leisure-time section of the International Physical Activity Questionnaire $^{(15)}$ and defined as inactive (no activity) or somewhat active. Food insecurity (lack of availability and access to food) was measured using the Brazilian Food Insecurity Scale. ${ }^{(16)}$ Stress was measured by the Perceived Stress Scale, ${ }^{(17)}$ and depressive symptoms were obtained using the Patient Health Questionnaire-9 (PHQ-9). ${ }^{18)}$

Concomitant to data collection, a $10.5 \%$ partial reproduction of the instrument was performed for data quality control (Kappa index of 0.80 ). The questionnaires were coded, reviewed, and double typed using the EpiData program, version 3.1, and the data were later transferred to the Stata statistical package, version 11.2, performing exploratory analysis of the database, transformation, and categorization of the variables.

We started with a descriptive analysis, describing the absolute and relative frequencies of the variables. 
Bivariate and multivariable analysis was performed using Poisson regression, considering the effect of sample design as 1.3. The multivariable analysis was done in levels, controlling the variables for those of the same level or levels above. The variables were divided into four levels: first, demographic and socioeconomic; second, behavioral; third, health; and fourth, health services. Wald test for heterogeneity was used, maintaining the adjusted model variables with a $p$-value of $\leq 0.20$. The level of statistical significance was set at $5 \%$ for two-tailed tests.

The project was approved by the Health Research Ethics Committee of the Universidade Federal do Rio Grande (FURG) (CAAE: 52939016.0.0000.5324). Participants signed the Informed Consent Form (ICF) and, if illiterate, consented by fingerprint after the form was read aloud.

\section{RESULTS}

The sample was composed of 680 individuals (90\% response rate). The mean age was 55 years (standard deviation - SD =17), ranging from 18 to 96 years. In the sample, $59.3 \%$ were female; $52 \%$ had zero to 8 years of schooling; $45.9 \%$ were 60 years or older; $84.3 \%$ reported being white, and $44 \%$ were married. Smokers were $17.5 \%$, those who consumed alcohol in excess $9 \%$, approximately $69 \%$ did not perform physical activity; $33.5 \%$ had food insecurity, $45 \%$ perceived their health as regular or bad, and $29.7 \%$ had depressive symptoms; $47.5 \%$ had no health insurance, $17.4 \%$ had not seen a physician in the last year, and $23.5 \%$ reported having received a visit from a community health worker at home, while $34.9 \%$ reported a home registered at a Primary Healthcare Unit (Table 1).

On table 2, the risk groups were separated, in descending order, according to the outcome.

The prevalence of individuals in the risk group not immunized in the last 12 months was $46.0 \%$ (95\% confidence interval - 95\% CI: 41.8-50.3), ranging from $27.9 \%$ (elderly) to $65.3 \%$ (had not seen a physician in the last year), and $65.5 \%$ for individuals aged 18 to 39 years (Table 3 ).

Adjusted for possible confounders, the following remained associated: young (18 to 39 years), single, intermediate economic status, smoking, depressive symptoms, and not having seen a physician in the past year. Excessive alcohol consumption and stress level lost association; not engaged in physical activity during leisure time gained association $(\mathrm{p}=0.04)$, and domicile not registered at a Primary Healthcare Unit remained associated with threshold statistical significance (prevalence ratio - $\mathrm{PR}=1.19 ; 95 \% \mathrm{CI}$ : 0.99-1.43) after adjustments (Table 3 ).
Table 1. Characteristics of the sample comprising the risk groups for vaccination against influenza

\begin{tabular}{|c|c|}
\hline Variable & n (\%) \\
\hline \multicolumn{2}{|l|}{ Sex } \\
\hline Male & $277(40.7)$ \\
\hline Female & $403(59.3)$ \\
\hline \multicolumn{2}{|l|}{ Age range, years } \\
\hline $18-39$ & $145(21.3)$ \\
\hline $40-59$ & $223(32.8)$ \\
\hline$\geq 60$ & $312(45.9)$ \\
\hline \multicolumn{2}{|l|}{ Skin color } \\
\hline White & $573(84.3)$ \\
\hline Others & $107(15.7)$ \\
\hline \multicolumn{2}{|l|}{ Marital status } \\
\hline Married & $299(44.0)$ \\
\hline Single & $211(31.0)$ \\
\hline Widowed, separated & $170(25.0)$ \\
\hline \multicolumn{2}{|l|}{ Schooling, years } \\
\hline $0-8$ & $353(52.0)$ \\
\hline $9-11$ & $197(29.0)$ \\
\hline$\geq 12$ & $129(19.0)$ \\
\hline \multicolumn{2}{|l|}{ Asset index } \\
\hline Poorer & $246(36.2)$ \\
\hline Intermediate & $203(29.9)$ \\
\hline Richer & $230(33.9)$ \\
\hline \multicolumn{2}{|l|}{ Smoking } \\
\hline No & $561(82.5)$ \\
\hline Yes & $119(17.5)$ \\
\hline \multicolumn{2}{|c|}{ Excessive alcohol consumption } \\
\hline No & $617(91.0)$ \\
\hline Yes & $61(9.0)$ \\
\hline \multicolumn{2}{|l|}{ Physical activity } \\
\hline No & 470 (69.3) \\
\hline Yes & $208(30.7)$ \\
\hline \multicolumn{2}{|l|}{ Food insecurity } \\
\hline No & $452(66.5)$ \\
\hline Yes & $228(33.5)$ \\
\hline \multicolumn{2}{|l|}{ Stress, terciles } \\
\hline Least stressed & $245(36.2)$ \\
\hline Intermediate & $230(33.9)$ \\
\hline Most stressed & $203(29.9)$ \\
\hline \multicolumn{2}{|l|}{ Perception of health } \\
\hline Excellent/Nery good & $104(15.3)$ \\
\hline Good & $270(39.7)$ \\
\hline Regular/Poor & $306(45.0)$ \\
\hline \multicolumn{2}{|l|}{ Depressive symptoms } \\
\hline No & $477(70.3)$ \\
\hline Yes & $201(29.7)$ \\
\hline \multicolumn{2}{|l|}{ Health insurance } \\
\hline No & $323(47.5)$ \\
\hline Yes & $357(52.5)$ \\
\hline \multicolumn{2}{|c|}{ Consultation with physician } \\
\hline No & $118(17.4)$ \\
\hline Yes & $562(82.6)$ \\
\hline \multicolumn{2}{|c|}{ Community health worker } \\
\hline No/does not know & $520(76.5)$ \\
\hline Yes & $160(23.5)$ \\
\hline \multicolumn{2}{|c|}{$\mathrm{PHU}$ in the neighborhood } \\
\hline No/does not know & $442(65.1)$ \\
\hline Yes & $237(34.9)$ \\
\hline
\end{tabular}


Table 2. Description of risk groups and prevalence of non-vaccination

\begin{tabular}{lcc}
\hline Risk group & $\mathbf{n ~ ( \% )}$ & Prevalence of non-vaccination (\%) \\
\hline Pregnant women & $11(1.6)$ & 81.8 \\
\hline Ischemia (stroke) & $38(5.6)$ & 56.8 \\
Chronic respiratory disease & $201(30.0)$ & 52.2 \\
Cardiopathy & $133(19.5)$ & 47.0 \\
Morbid obesity & $13(2.0)$ & 46.2 \\
\hline Hypertension & $366(53.6)$ & 44.4 \\
Cancer & $37(5.4)$ & 43.2 \\
Diabetes & $90(13.2)$ & 41.1 \\
Renal failure & $34(5.0)$ & 36.4 \\
Elderly & $315(46.1)$ & 27.9 \\
\hline Total & $680(100.0)$ & 46.0 \\
\hline
\end{tabular}

Table 3. Crude and adjusted analysis of the prevalence of non-vaccination against influenza for risk groups

\begin{tabular}{|c|c|c|c|}
\hline Variable & $\begin{array}{c}\text { Prevalence } \\
(\%)\end{array}$ & $\begin{array}{l}\text { Crude analysis } \\
\text { PR (95\% CI) }\end{array}$ & $\begin{array}{c}\text { Adjusted } \\
\text { analysis PR } \\
(95 \% \mathrm{CI})\end{array}$ \\
\hline Sex & & $p=0.63$ & $p=0.68$ \\
\hline Male & 46.9 & 1.00 & 1.00 \\
\hline Female & 45.4 & $1.03(0.90-1.18)$ & $1.03(0.90-1.18)$ \\
\hline Age range, years & & $p<0.01$ & $p<0.01$ \\
\hline $18-39$ & 65.5 & $2.34(1.84-3.00)$ & $2.06(1.57-2.69)$ \\
\hline $40-59$ & 58.7 & $2.11(1.66-2.67)$ & $2.03(1.60-2.58)$ \\
\hline$\geq 60$ & 27.9 & 1.00 & 1.00 \\
\hline Skin color & & $p=0.95$ & $p=0.52$ \\
\hline White & 46.1 & 1.00 & 1.00 \\
\hline Others & 45.8 & $0.99(0.81-1.23)$ & $0.93(0.75-1.16)$ \\
\hline Marital status & & $p<0.01$ & $p=0.12$ \\
\hline Married & 40.5 & 1.00 & 1.00 \\
\hline Single & 62.1 & $1.53(1.26-1.86)$ & $1.24(1.01-1.52)$ \\
\hline Widowed/Separated & 35.9 & $0.89(0.69-1.14)$ & $1.03(0.82-1.30)$ \\
\hline Schooling, years & & $p=0.09$ & $p=0.68$ \\
\hline $0-8$ & 41.9 & $0.86(0.70-1.05)$ & $1.01(0.82-1.25)$ \\
\hline $9-11$ & 51.8 & $1.06(0.82-1.37)$ & $1.12(0.86-1.42)$ \\
\hline$\geq 12$ & 48.8 & 1.00 & 1.00 \\
\hline Asset index & & $p=0.01$ & $p=0.06$ \\
\hline Poorest & 45.1 & $1.15(0.95-1.41)$ & $1.15(0.96-1.39)$ \\
\hline Intermediate & 54.7 & $1.40(1.14-1.72)$ & $1.28(1.05-1.26)$ \\
\hline Richest & 39.1 & 1.00 & 1.00 \\
\hline Smoking & & $p<0.01$ & $p=0.02$ \\
\hline No & 42.6 & 1.00 & 1.00 \\
\hline Yes & 62.2 & $1.46(1.19-1.79)$ & $1.27(1.04-1.54)$ \\
\hline Excessive alcohol consumption & & $p=0.03$ & $p=0.12$ \\
\hline No & 44.6 & 1.00 & 1.00 \\
\hline Yes & 62.3 & $1.40(1.11-1.76)$ & $1.20(0.95-1.52)$ \\
\hline Physical activity & & $p=0.07$ & $p=0.04$ \\
\hline No & 48.3 & $1.20(0.99-1.45)$ & $1.18(1.01-1.38)$ \\
\hline Yes & 40.4 & 1.00 & 1.00 \\
\hline
\end{tabular}

Continuation

Table 3. Crude and adjusted analysis of the prevalence of non-vaccination against influenza for risk groups

\begin{tabular}{|c|c|c|c|}
\hline Variable & $\begin{array}{c}\text { Prevalence } \\
(\%)\end{array}$ & $\begin{array}{l}\text { Crude analysis } \\
\text { PR (95\%Cl) }\end{array}$ & $\begin{array}{c}\text { Adjusted } \\
\text { analysis PR } \\
(95 \% \mathrm{CI})\end{array}$ \\
\hline Food insecurity & & $p<0.01$ & $p=0.24$ \\
\hline No & 40.4 & 1.00 & 1.00 \\
\hline Yes & 57.9 & $1.45(1.20-1.74)$ & $1.13(0.92-1.38)$ \\
\hline Stress, terciles & & $p=0.02$ & $p=0.54$ \\
\hline Least stressed & 41.6 & 1.00 & 1.00 \\
\hline Intermediates & 42.6 & $1.02(0.83-1.26)$ & $0.94(0.77-1.16)$ \\
\hline Most stressed & 55.2 & $1.33(1.07-1.65)$ & $1.07(0.85-1.35)$ \\
\hline Perception of health & & $p=0.67$ & $p=0.31$ \\
\hline Excellent/Very good & 50.0 & 1.00 & 1.00 \\
\hline Good & 44.4 & $0.89(0.68-1.16)$ & $0.89(0.70-1.14)$ \\
\hline Regular/Poor & 46.1 & $0.92(0.71-1.20)$ & $0.82(0.63-1.06)$ \\
\hline Depressive symptoms & & $p<0.01$ & $p=0.02$ \\
\hline No & 40.9 & 1.00 & 1.00 \\
\hline Yes & 58.2 & $1.42(1.21-1.68)$ & $1.23(1.03-1.46)$ \\
\hline Health insurance & & $p=0.23$ & $p=0.28$ \\
\hline No & 48.9 & $1.13(0.93-1.37)$ & $0.91(0.76-1.08)$ \\
\hline Yes & 43.4 & 1.00 & 1.00 \\
\hline Consultation with physician & & $p<0.01$ & $p<0.01$ \\
\hline No & 65.3 & $1.55(1.35-1.78)$ & $1.54(1.36-1.75)$ \\
\hline Yes & 42.0 & 1.00 & 1.00 \\
\hline Community health worker & & $p=0.81$ & $p=0.47$ \\
\hline No/does not know & 45.6 & $0.98(0.80-1.20)$ & $0.93(0.75-1.15)$ \\
\hline Yes & 46.9 & 1.00 & 1.00 \\
\hline PHU in the neighborhood & & $p=0.46$ & $p=0.07$ \\
\hline No/does not know & 47.3 & $1.08(0.88-1.32)$ & $1.19(0.99-1.43)$ \\
\hline Yes & 43.9 & 1.00 & 1.00 \\
\hline
\end{tabular}

PR: prevalence ratio; 95\% Cl: 95\% confidence interval; PHU: Primary Health Unit.

\section{DISCUSSION}

After investigating the prevalence and factors associated with non-immunization against influenza in risk groups, approximately half of the individuals reported non-immunization in the 12 months prior to the interview. After adjustments, the following were associated with the outcome: young (18 to 39 years), single, intermediate economic level, smoking, no physical activity during leisure time, depressive symptoms, not having seen a physician in the last year, and home not being registered at the Primary Healthcare Unit.

Similar to the present results, regarding the prevalence of non-vaccination, both the Korean study with 1,650 adults in the risk group, conducted in 2009 and 2010, in which $53 \%$ had not been immunized, ${ }^{(8)}$ and another study conducted in Massachusetts, United States, in which $56 \%$ of adults who responded to the 
Behavioral Risk Factor Surveillance System (BRFSS) were not vaccinated, ${ }^{(9)}$ demonstrating the difficulty in reaching the goal of $75 \%$ vaccination against influenza in the risk population. ${ }^{(19)}$ It is possible to consider the role of the media, which highlights the adverse effects, providing greater perception, ${ }^{(12)}$ and the worldwide antivaccine movement, which does not recognize its social benefit, and despite affecting mainly children (the most dense and specific vaccination schedule), has supporters in both the risk group and their caregivers. ${ }^{(12)}$

Corroborating the data of this study, $40 \%$ out of 47 thousand diabetics who responded to the BRFSS in $2011,{ }^{(20)}$ and $58 \%$ of Brazilian adults and the elderly with chronic pulmonary respiratory disease who responded to the National Survey on Access, Use, and Promotion of Rational Use of Medicines, in 2013 and 2014, were not vaccinated. ${ }^{(21)}$ In the elderly, a group with a lower prevalence in these results, Brazilian studies pointed out a coverage gap between one quarter and one third (22-24) relative to the prevalence of $27.4 \%$, according to the 2013 National Health Survey (PNS). ${ }^{(25)}$

The highest likelihood of non-vaccination among young people in this sample contributes to previous statistically significant evidence. In South Korea, the percentage of non-vaccinated individuals was one-third lower when comparing those $\leq 59$ years and $\geq 60$ years, with more than $90 \%$ non-compliance in the first group. ${ }^{(8)}$ North-Americans, based on the BRFSS, indicated a $20 \%$ to $30 \%$ higher probability of an individual between 25 and 49 years not being vaccinated against influenza, as compared to those between 50 and 64 years. ${ }^{(9)}$ In diabetics, the chance of young adults not being vaccinated was twice as high compared to the elderly. ${ }^{(20)}$ In pregnant women, although $1.6 \%$ of sample, nonvaccination for more than $80 \%$ contributed to the prevalence among young adults. A systematic review pointed out subjective trends for non-vaccination among young people: living alone, not being concerned about influenza, and little social pressure to be vaccinated.(12)

Analyses of risk groups showed that single individuals have a higher chance of not being vaccinated compared to married couples. ${ }^{(9,20,21)}$ This allows us to consider that the marital relationship has an important influence on vaccination of the adult population, except after 60 years in studies containing only the elderly, ${ }^{(21-24)}$ either by understanding the benefits of vaccination, the emphasis on the elderly as a Risk Group in the campaign, because there is more time available, or by prioritizing their health at this stage of life at the expense of other tasks previously more valued.
The intermediate economic tercile, even with the vaccine provided by SUS, was associated with the outcome, while the income extremes were more likely to be vaccinated, similar to what was shown in Taiwan, between 1999 and 2012. ${ }^{(26)}$ A possible hypothesis would be related to the coverage of public and supplementary health services, where the poorest use the SUS and the Primary Healthcare Unit network, while the richest engage more private plans. Thus, the intermediate tercile may feel helpless for not having coverage in the Primary Healthcare Unit area (gaps in the different neighborhoods and difficult logistics of referral by the user's address) nor economic conditions for private care.

There was no relation between non-vaccination and schooling in this sample, unlike what was found in studies, both in Campinas (SP) including the elderly, ${ }^{(22)}$ and in Rio Grande with pregnant women. ${ }^{(27)}$ Therefore, schooling is not necessarily linked to the population's knowledge, based on the benefits of vaccination, considering the educational nature aimed by the campaign of the Ministry of Health. . $^{(3,4,28)}$

Even though the harm of smoking is well known, in this sample, $17.5 \%$ were smokers. There was a higher prevalence of non-vaccinated among smokers, similar to the American studies including diabetics $(52 \%)^{(20)}$ or the elderly (63\%), ${ }^{(9)}$ and to the 2013 National Health Survey in Brazil, according to which $12.7 \%$ of elderly were smokers; smoking was also a factor associated with non-vaccination. ${ }^{(25)}$ Smoking may be related to a lower tendency to seek primary prevention, as concluded in a systematic review. ${ }^{(12)}$

Not performing physical activity during leisure time permeated most of the sample, with a statistically significant relation with the outcome. Such data was also present specifically among the elderly. ${ }^{(22,24)}$ The performance of physical activity is related to greater health care, and data suggested individuals with unhealthy habits were less likely to seek primary prevention. ${ }^{(12)}$

A disturbing fact was that $29.7 \%$ of interviewees presented with depressive symptoms. The presence of comorbidities increases the prevalence of these symptoms ${ }^{(29)}$ and home confinement is present in most patients. ${ }^{(30)}$ When assessing the presence of depressive symptoms, a higher probability of non-vaccination was observed in up to $46 \%$, with home confinement and loss of interest as possible justifications. ${ }^{(24)}$

Individuals who had not seen a physician in the last year were the most susceptible to non-vaccination for influenza. This association was also observed in the BRFSS 
2009-2010, ${ }^{(9)}$ as well as in the elderly who participated in both the 2013 National Health Survey and the 2010 São Paulo survey. ${ }^{(24,25)}$ Among pregnant women in the city of Rio Grande, the non-vaccination rate in those who did not undergo prenatal care was up to 20 times higher. (27) $^{2}$ This reinforces the importance of guidance as to primary prevention, as is highlighted in a systematic review; the probability of non-vaccination is higher in those who interact less with the health system, have fewer medical appointments, and do not have a source of regular care..$^{(12)}$

Those who knew that their household was registered in the Primary Healthcare Unit were less likely to not to be vaccinated, showing a borderline association after adjustments. A study with the elderly reported this relation with statistical significance, ${ }^{(25)}$ expressing the benefits of health systems, management, and implementation of logistics per area of the Primary Healthcare Unit.

As possible limitations, we point out the noninclusion of all risk groups referenced by the Ministry of Health. ${ }^{(4)}$ Moreover, the outcome was measured by a single question, due to the scope of the survey. The response was self-reported, which, added to the data collection period (April to July), makes recall error possible.

As strengths, we mention the fact that it is a population-based study with a good response rate (90\%), including several risk groups. After literature review, it is the only national study with such a combination of data. It has potential for data extrapolation to other municipalities with similar sociocultural contexts, and it is a tool to help identify profiles with failures to achieve the goals of vaccination against influenza.

\section{CONCLUSION}

When investigating prevalence and factors associated with non-vaccination against influenza in risk groups, it was evident that half of the individuals were not vaccinated in the period. Considering the similarity of the influenza-like illness and the current COVID-19 pandemic, which shows higher mortality among the elderly and patients with chronic non-communicable diseases, an increase of primary prevention would reduce the higher mortality rate from influenza, and the use of inpatient and intensive care unit beds, optimizing the response of the installed hospital capacity.

\section{ACKNOWLEDGEMENTS}

Research financed by Fundação de Amparo à Pesquisa do Estado do Rio Grande do Sul (FAPERGS), Introduction to Programa de Iniciação Científica - ARD/PPP 2014, grant 16/2551-0000359-9. Kevin Francisco Durigon Meneghini is scientific research grantee from FAPERGS, and Samuel Carvalho Dumith is a research productivity grantee from the Conselho Nacional de Desenvolvimento Científico e Tecnológico (CNPq).

\section{AUTHORS' CONTRIBUTION}

Kevin Francisco Durigon Meneghini and Camila Furtado Hood wrote the manuscript; Raúl Andrés Mendoza-Sassi and Letícia Oliveira de Menezes critically revised the manuscript; Samuel Carvalho Dumith conceived the study, analyzed data and critically revised the manuscript.

\section{AUTHORS' INFORMATION}

Meneghini KF: http://orcid.org/0000-0002-2231-7389

Hood CF: http://orcid.org/0000-0003-2436-0740

Menezes LO: http://orcid.org/0000-0001-5393-8770

Mendoza-Sassi RA: http://orcid.org/0000-0002-4641-9056

Dumith SC: http://orcid.org/0000-0002-5994-735X

\section{REFERENCES}

1. Pôrto Â, Ponte CF. Vacinas e campanhas: as imagens de uma história a ser contada. Hist Cienc Saude-Manguinhos. 2003;10(Suppl 2):725-42.

2. Feijó RB, Sáfadi MA. Immunizations: three centuries of success and ongoing challenges. J Pediatr (Rio J). 2006;82(3 Suppl):S1-3.

3. Brasil. Ministério da Saúde. Secretaria de Vigilância em Saúde. Programa Nacional de Imunizações 30 anos. Brasília (DF): Ministério da Saúde; 2003 [citado 2020 Mar 28]. Disponível em: http://bvsms.saude.gov.br/bvs/ publicacoes/livro_30_anos_pni.pdf

4. Brasil. Ministério da Saúde. Coordenação Geral do Programa Nacional de Imunizações. Informe técnico: $22^{\text {a }}$ Campanha Nacional de Vacinação contra a Influenza. Brasília (DF): CGPNl; 2020 [citado 2020 Mar 28]. Disponível em: https://sbim.org.br/images/files/notas-tecnicas/informe-tecnico-mscampanha-influenza-2020-final.pdf

5. Brasil. Ministério da Saúde. Sistema de Informações do Programa Nacional de Imunizações (SIPNI). Campanha Nacional de Vacinação Contra Influenza 2020. Brasília (DF): SIPNI; 2020 [citado 2020 Abr 3]. Disponível em: http://sipni-gestao.datasus.gov.br/si-pni-web/faces/relatorio/consolidado/ coberturaVacinalCampanhalnfluenza.jsf

6. Sociedade Brasileira de Imunizações (SBIM). Informe técnico - 09/04/2020: vacinação de rotina durante a pandemia de COVID-19. São Paulo: SBIM; 2020 [citado 2020 Mar 28]. Disponível em: https://sbim.org.br/images/files/ notas-tecnicas/nota-tecnica-sbim-vacinacao-rotina-pandemia.pdf

7. Daufenbach LZ, Duarte EC, Carmo EH, Campagna AS, Santos CA. Morbidade hospitalar por causas relacionadas à influenza em idosos no Brasil, 1992 a 2006. Epidemiol Serv Saúde. 2009;18(1):29-44.

8. Heo JY, Chang SH, Go MJ, Kim YM, Gu SH, Chun BC. Risk perception, preventive behaviors, and vaccination coverage in the Korean population during the 2009-2010 pandemic influenza A (H1N1): comparison between high-risk group and non-high-risk group. PLoS One. 2013;8(5):e64230.

9. Lu PJ, Gonzalez-Feliciano A, Ding H, Bryan LN, Yankey D, Monsell EA, et al Influenza A (H1N1) 2009 monovalent and seasonal influenza vaccination among adults 25 to 64 years of age with high-risk conditions--United States, 2010. Am J Infect Control. 2013;41(8):702-9. 
10. Brasil. Ministério da Saúde. Secretarias Estaduais de Saúde. Coronavírus (COVID-19); COVID-19 no Brasil. Brasília (DF): Ministério da Saúde; 2020 [citado 2020 Jul 12]. Disponível em: https://susanalitico.saude.gov.br/\#/ dashboard/

11. Brasil. Ministério da Saúde. Tecnologia da Informação a Serviço do Sistema único de Saúde (DATASUS). Morbidade hospitalar do SUS - por local de residência - Brasil. Brasília (DF): Ministério da Saúde; 2020 [citado 2020 Abr 6]. Disponível em: http://tabnet.datasus.gov.br/cgi/tabcgi.exe?sih/cnv/nruf.def

12. Schmid P, Rauber D, Betsch C, Lidolt G, Denker ML. Barriers of influenza vaccination intention and behavior - a systematic review of influenza vaccine hesitancy, 2005 - 2016. PLoS One. 2017;12(1):e0170550.

13. Dumith SC, Paulitsch RG, Carpena MX, Muraro MF, Simões MO, Machado KP, et al. Planejamento e execução de um inquérito populacional de saúde por meio de consórcio de pesquisa multidisplinar. Sci Med. 2018;28(3):ID30407.

14. World Health Organization (WHO). Global status report on alcohol and health 2014. Geneva: WHO; 2014 [cited 2020 Jul 13]. Available from: https://apps. who.int/iris/bitstream/handle/10665/112736/9789240692763 eng.pdf;jses sionid =1D3CCBC52732B4679780DF859E5E1A59? sequence $=\overline{1}$

15. Craig CL, Marshall AL, Sjöström M, Bauman AE, Booth ML, Ainsworth BE, et al. International physical activity questionnaire: 12-country reliability and validity. Med Sci Sports Exerc. 2003;35(8):1381-95.

16. Segall-Corrêa AM, Marin-León L, Melgar-Quiñonez H, Pérez-Escamilla R. Refinement of the Brazilian household food insecurity measurement scale: recommendation for a 14-item EBIA. Rev Nutr. 2014;27(2):241-51.

17. Reis RS, Hino AA, Añez CR. Perceived stress scale: reliability and validity study in Brazil. J Health Psychol. 2010;15(1):107-14.

18. Santos IS, Tavares BF, Munhoz TN, Almeida LS, Silva NT, Tams BD, et al. Sensibilidade e especificidade do Patient Health Questionnaire-9 (PHO-9) entre adultos da população geral. Cad Saude Publica. 2013;29(8):1533-43.

19. Monto AS. Seasonal influenza and vaccination coverage. Vaccine. 2010; 28(Suppl 4):D33-44. Review.

20. Athamneh LN, Sansgiry SS. Influenza vaccination in patients with diabetes: disparities in prevalence between African Americans and Whites. Pharm Pract (Granada). 2014;12(2):410.
21. Bacurau $A G$, Francisco PM. Prevalence of influenza vaccination in adults and elderly with chronic respiratory diseases. Cad Saude Publica. 2018; 34(5):e00194717.

22. Francisco PM, Barros MB, Cordeiro MR. Vacinação contra influenza em idosos: prevalência, fatores associados e motivos da não-adesão em Campinas, São Paulo, Brasil. Cad Saude Publica. 2011;27(3):417-26.

23. Dip RM, Cabrera MA. Influenza vaccination in non-institutionalized elderly: a population-based study in a medium-sized city in Southern Brazil. Cad Saude Publica. 2010;26(5):1035-44.

24. Sato AP, Antunes JL, Moura RF, de Andrade FB, Duarte YA, Lebrão ML. Factors associated to vaccination against influenza among elderly in a large Brazilian metropolis. PLoS One. 2015;10(4):e0123840.

25. Bof de Andrade F, Sato AP, Moura RF, Antunes JL. Correlates of influenza vaccine uptake among community-dwelling older adults in Brazil. Hum Vaccin Immunother. 2017;13(1):103-10.

26. Hsu PS, Lian IB, Chao DY. A population-based propensity score-matched study to assess the impact of repeated vaccination on vaccine effectiveness for influenza-associated hospitalization among the elderly. Clin Interv Aging. 2020;15:301-12.

27. Mendoza-Sassi RA, Linhares AO, Schroeder FM, Maas NM, Nomiyama S, César JA. Vaccination against influenza among pregnant women in southern Brazil and associated factors. Cien Saude Colet. 2019;24(12):4655-64.

28. Nakamura EY, Mello LM, Silva AS, Nunes AA. Prevalence of influenza and adherence to the anti-flu vaccination among elderly. Rev Soc Bras Med Trop. 2012;45(6):670-4.

29. Brasil. Ministério da Saúde. Depressão: causas, sintomas, tratamentos, diagnóstico e prevenção. Brasília (DF): Ministério da Saúde; 2020 [citado 2020 Apr 11]. Disponível em: https://www.tjdft.jus.br/informacoes/ programas-projetos-e-acoes/pro-vida/dicas-de-saude/pilulas-de-saude/ depressao-causas-sintomas-tratamentos-diagnostico-e-prevencao

30. American Psychiatric Association (APA). Diagnostic and statistical manual of mental disorders (DSM-5). 5th ed. Washington (DC): APA; 2013. p. 991. 